\title{
Commentary: Landmark Articles on Copper in the Field of Human Health
}

\author{
George J. Brewer \\ Department of Human Genetics, The University of Michigan Medical School, \\ Ann Arbor, Michigan
}

In deciding on an appropriate paper for this topic, we had to first choose between copper deficiency and copper toxicity. Copper deficiency is a common problem in some animals species, but is rare in the human. It occasionally occurs on a dietary basis, bowel surgery basis, or overtreatment with anticopper drugs. It is also a major clinical problem in the rare inherited condition, Menke's disease. Progress has been made in the understanding of Menke's disease, particularly with the cloning of the gene responsible, known as ATP7A [1-3]. Thus, a landmark article could have reasonably been selected from the Menke's disease area.

Copper toxicity is also a common problem in some animals species (e.g. sheep), and is, again, rare in the human. It is a major clinical problem in the relatively rare inherited condition, Wilson's disease. As in Menke's disease, the gene responsible, known as ATP7B, has been cloned [4-6], and this knowledge is leading to a better understanding of the mechanism of the disease process. In choosing between the two diseases, we took into consideration that a major difference exists between Menke's disease and Wilson's disease, in that the latter is so effectively treated, while the former is not. In thinking about "impact on human health," we felt it important to not only consider intellectual understanding of the disease process, but whether understanding has led to better treatment. This is clearly the case with Wilson's disease but not with Menke's disease. Therefore, we decided to choose a paper from the Wilson's disease area, and to look at the entire scope of discovery so far, in choosing the paper most deserving of this reward.

In deciding which contribution in Wilson's disease to honor, we had many choices. We will briefly go through the major historical highlights for background purposes. Wilson himself, for whom the disease is named, obviously deserves enormous credit for bringing diverse neurological and hepatic observations together into the "hepatolenticular degeneration" syndrome [7]. But he had no hint that the disease was due to copper, so in our opinion, his work doesn't qualify for this particular landmark, which deals with the impact of copper-related discoveries on human health. Kayser [8] and Fleischer [9] early observed the corneal abnormalities that bear their names (KayserFleischer rings) which have been very useful in diagnosis. Fleischer [10] even detected an increase of copper in these rings in a patient. However, there was no suggestion at this point that the disease was caused by copper.

The key etiological role of copper was missed early and often, as investigators

Received 24 July 2000; Accepted 3 February 2001

(C) 2001 Wiley-Liss, Inc. 
found elevated levels of copper in various locations, but usually failed to realize its significance. After Fleischer in 1912 observed elevated copper in the cornea, Rumpel in 1913 [11], Vogt in 1929 [12], and Haurowitz in 1930 [13] observed elevated hepatic copper levels in Wilson's disease patients. Glazebrook in 1945 [14] and Cumings in 1948 [15] detected elevated copper in both liver and brain tissue in patients, and for the first time, began to discuss an etiological role for copper. We'll return to those two papers in a moment. In 1948, Mandelbrote [16] detected an elevated urine copper in a patient with Wilson's disease, and showed that urinary copper increased with British Antilewisite (BAL) injections.

Other important historical milestones include the first specific anticopper treatment of Wilson's disease patients with BAL injections in 1951 by Cumings [17], the discovery of a low level in the plasma of Wilson's disease patients of the coppercontaining protein, ceruloplasmin in 1952 by two sets of investigators (Bearn and Kunkel [18], and Scheinberg and Gitlin [19], and the working out of autosomal recessive inheritance in 1960 by Bearn [20]. In 1944, Ravesteyn [21] had gone a long way towards showing that copper balance in normal people is regulated by biliary excretion of copper, and in 1974 Frommer [22] demonstrated that the defect in Wilson's disease was a failure of biliary copper excretion.

Oral anticopper therapy ushered in a management era that was much improved for these patients and began with the introduction of penicillamine, a chelating agent that enhances urinary excretion of copper, by Walshe, in 1956 [23]. Walshe followed this up by introducing an alternative chelator, trientine, in 1982 [24]. Schouwink's thesis at the University of Amsterdam in 1961 [25] discussed treatment of two patients with zinc, but went unnoticed because it was not published in the general literature. In 1983, we published our first paper on zinc therapy in Wilson's disease [26], and have gone on to publish over 50 papers on this topic, culminating in the U.S. FDA approval of zinc acetate for Wilson's disease in 1997. In 1987, we identified the frequent problem of neurological worsening of neurologically-presenting patients when treated with penicillamine [27], and in 1991 introduced tetrathiomolybdate as an initial therapy for this type of patient [28].

In 1993, the causative gene for Wilson's disease, known as ATP7B, was identified by three groups working independently (Bull et al. [4]; Tanzi et al. [5]; Yamaguchi et al. [6]). The LEC rat, first shown by $\mathrm{Li}$ et al. in 1991 [29] to sequester hepatic copper, is an ideal animal model because it has been shown by Wu et al. [30] and Sasaki et al. [31] in 1994, to involve the rat homologue of ATP7B. The same is true of the "toxic milk" mouse, as shown by Theophilos et al. in 1996 [32].

With so many important contributions to this disease of copper toxicity, how do we choose the most important to honor as a landmark article? We decided that the seminal studies regarding copper in this disease were those that identified an etiological role for copper in causing the disease. It was from the basic concept of copper causation that specific anticopper therapies were developed, and the gene itself cloned. (Gene cloning led from cloning ATP7A, the causative gene in Menke's disease, already known to be another disorder of copper metabolism.)

In looking back at the trail of papers relating copper abnormalities to Wilson's disease, we believe two papers were most critical in developing the concept of a copper etiology. These are the papers by Glazebrook (Wilson's disease. Edinburgh Med J 52:83-87, 1945 [14]) and Cummings (The copper and iron content of brain and 
liver in the normal and in hepatolenticular degeneration. Brain 71:410-415, 1948 [15]). These two papers are reproduced here, to honor their contributions.

The paper by Glazebrook [14] describes two cases of Wilson's disease. The second patient died in hospital and an autopsy was carried out. While the patient was still alive, the author had shown that the patient's blood copper was elevated. At autopsy, he was able to show that the copper was elevated in both the liver and basal ganglia of the brain, and to a lesser extent the brain cortex. Glazebrook goes on in this paper to discuss how copper toxicity might damage the brain. He points out that "copper is a powerful inhibitor of enzymic activity, even in dilute solution," and "the exceptionally rich blood supply of the basal ganglia affords an indication of the great respiratory demands of these tissues, and they are in fact peculiarly susceptible to damage by inhibitors of enzymic activity, such as cyanide and carbon monoxide." Perhaps we can still learn from these remarks. We still don't understand the special sensitivity to copper of these regions of the brain, and perhaps Glazebrook's insight should lead us into further thinking about the special metabolic features of these regions.

More than this, however, was the particularly insightful remark in the summary, which happens to be the last sentence in the paper: "Inability to excrete copper may be the liver dysfunction responsible for the production of lenticular degeneration." This statement, made in this 1945 paper [14], turns out to be right on target. It would be 29 years later before it was shown that a defect in biliary excretion of copper caused Wilson's disease [22].

The second paper we honor is that of Cumings [15]. This paper was published three years after that of Glazebrook, and confirmed the elevated copper in the livers and brains of Wilson's disease patients, but in a larger number of patients. This paper continued developing the theme of the etiological role of copper, "By analogy, it would also seem possible that hepatolenticular degeneration is an inborn error in mineral metabolism." And, "The possibility that the condition is a metabolic disorder similar to that of haemochromatosis has been discussed."

But perhaps the most important contribution in this paper [15] is the movement of Cumings' thinking toward using the etiological role of copper as a reason to consider anticopper therapy. For example, talking about anticopper therapy with BAL, he said, "It might also be used in an attempt to reduce the copper content of the liver and brain, and possibly thereby to prevent further damage to the tissues." Cumings then initiated a BAL therapy trial [17], with some success, and therapy of this disease, later to become so successful, was off and running.

\section{REFERENCES}

1. Vulpe C, Levinson B, Whiney S, Packman S, Gitschier J. Isolation of a candidate gene for Menkes disease and evidence that it encodes a copper-transporting ATP-ase. Nat Genet 1993;3:7-13.

2. Chelly J, Tumer Z, Tonnesen T, Petterson A, Ishikawa-Brush Y, Tommerup N, Horn N, Monaco AP. Isolation of a candidate gene for Menkes disease that encodes a potential heavy metal binding protein. Nat Genet 1993;3:14-19.

3. Mercer JF, Livingston J, Hall B, Paynter JS, Begy C, Chandrasekharappa S, Lockhart P, Grimes A, Bhave M, Siemieniak D. Isolation of a partial candidate gene for Menkes disease by positional cloning. Nat Genet 1993;3:20-25.

4. Bull PC, Thomas GR, Rommens JM, Forbes JR, Cox DW. The Wilson disease gene is a putative copper transporting P-type ATPase similar to the Menkes gene. Nature Genet 1993;5(4):327-337. 
5. Tanzi RE, Petrukhin K, Chernov I, Pellequer JL, Wasco W, Ross B, et al. The Wilson disease gene is a copper transporting ATPase with homology to the Menkes disease gene. Nature Genet 1993;5(4): 44-50.

6. Yamaguchi Y, Heiny ME, Gitlin JD. Isolation and characterization of a human liver cDNA as a candidate gene for Wilson disease. Biochem Biophys Res Commun 1993;197:271-277.

7. Wilson SAK. Progressive lenticular degeneration. A familial nervous disease associated with cirrhosis of the liver. Brain 1912;34:295-509.

8. Kayser B. Ueber einen Fall von angeborener grünlicher Verfärbung der kornea. Klin Mbl Augenheilk 1902;40:22-25.

9. Fleischer B. Zwei weitere Fälle von grünliche Verfärbung der Kornea. Klin Mbl Augenheilk 1903; 41:489-491.

10. Fleischer B. Ueber eine der 'Pseudosklerose' nahestehende bisher unbekante Krankeheit (gekennzeignet durch Tremor, psychische Störungen, braunliche Pigmentiergun bestimmter Gewebe, insbezondere Hoenhautperipheie, Lebercirrhose). Deutsch Zeitschrift für Nervenheilkunde 1912;44:179-201.

11. Rumpel A. Ueber das wesen un die bedeutung der leberveränderungen und der pigmentierunen bei den damit verbundenen fällen von pseudosklerose, zugleich ein beitrag zur lehre von pseudosklerose (Westphal-Strümpell). Dtsch Z Nervenheilk 1913:49:54-73.

12. Vogt A. Kupfer und silber aufgespeichert in auge, leber, milz und nieren als symptoms der pseudosklerose. Klin Mbl Augenheilk 1929;83:417-419.

13. Haurowitz F. Ueber eine anomalie des kupferstoffwechsels. Hoppe-Seviers Z Physiol Chemie 1930; 190:72-74.

14. Glazebrook AJ. Wilson's disease. Edinburgh Med J 1945;52:83-87.

15. Cumings JN. The copper and iron content of brain and liver in the normal and in hepatolenticular degeneration. Brain 1948;71:410-415.

16. Mandelbrote BM, Stanier MW, Thompson RHS, Thruston MN. Studies on copper metabolism in demyelinating disease of the central nervous system. Brain 1948;71:212-228.

17. Cumings JN. The effects of BAL in hepatolenticular degeneration. Brain 1951;74:10-22.

18. Bearn AG, Kunkel HG. Biochemical abnormalities in Wilson's disease. J Clin Invest 1952;31:616.

19. Scheinberg IH, Gitlin D. Deficiency of ceruloplasmin in patients with hepatolenticular degeneration (Wilson's disease). Science 1952;116:484-485.

20. Bearn AG. A genetical analysis of thirty families with Wilson's disease (hepatolenticular degeneration). Ann Hum Genet 1960;24:33-43.

21. Ravestyn AH. Metabolism of copper in man. Acta Med Scand 1944;118:163-196.

22. Frommer DJ. Defective biliary excretion of copper in Wilson's disease. Gut 1974;15:125-129.

23. Walshe JM. Penicillamine. A new oral therapy for Wilson's disease. Am J Med 1956;21:487-95.

24. Walshe JM. Treatment of Wilson's disease with trientine (triethylene tetramine) dihydrochloride. Lancet 1982;1:643-647.

25. Schouwink G. De hepatocerebrale degeneratie, me een onderzoek naar de zinktofwisseling. University of Amsterdam: MD Thesis, 1961.

26. Brewer GJ, Hill GM, Prasad AS, Cossack ZT, Rabbani P. Oral zinc therapy for Wilson's disease. Ann Intern Med 1983;99:314-320.

27. Brewer GJ, Terry CA, Aisen AM, Hill GM. Worsening of neurologic syndrome in patients with Wilson's disease with initial penicillamine therapy. Arch Neurol 1987;44:490-493.

28. Brewer GJ, Dick RD, Yuzbasiyan-Gurkin V, Tanakow R, Young AB, Kluin KJ. Initial therapy of patients with Wilson's disease with tetrathiomolybdate. Arch Neurol 1991;48:42-47.

29. Li Y, Togashi Y, Sato S, Emoto T, Kang J-H, Takeichi N, Kobayashi H, Kojima Y, Une Y, Uchino J. Spontaneous hepatic copper accumulation in Long-Evans Cinnamon rats with hereditary hepatitis: a model of Wilson's disease. J Clin Invest 1991;87:1858-1861.

30. Wu J, Forbes JR, Chen HS, Cox DW. The LEC rat has a deletion in the copper transporting ATPase gene homologous to the Wilson disease gene. Nature Genet 1994;7:541-545.

31. Sasaki N, Hayashizaki Y, Muramatsu M, Matsuda M, Ando Y, Kuramoto T, Srikawa T, Azuma T, Naito A, Agui T, Yamashita T, Miyoshi I, Takeichi N, Kasai N. The gene responsible for LEC hepatitis, located on rat chromosome 16, is the homolog to the human Wilson disease gene. Biochem Biophys Res Commun 1994;202:512-518.

32. Theophilos MB, Cox DW, Mercer JFB. The toxic milk mouse is a murine model of Wilson disease. Hum Molec Genet 1996;5:1619-1624. 